Article

\title{
RVFV Infection in Goats by Different Routes of Inoculation
}

\author{
Andrea L. Kroeker ${ }^{1, *}$, Valerie Smid ${ }^{1}$, Carissa Embury-Hyatt ${ }^{1}$, Estella Moffat ${ }^{1}$, Brad Collignon ${ }^{1}$, \\ Oliver Lung ${ }^{1,2}$, Robbin Lindsay ${ }^{3,4}$ and Hana Weingartl ${ }^{1,5, *}$ \\ 1 Canadian Food Inspection Agency, Winnipeg, MB R3E 3M4, Canada; valerie.smid@canada.ca (V.S.); \\ Carissa.emburyhyatt@canada.ca (C.E.-H.); estella.moffat@canada.ca (E.M.); brad.collignon@canada.ca (B.C.); \\ oliver.lung@canada.ca (O.L.) \\ 2 Department of Biological Sciences, University of Manitoba, Winnipeg, MB R3T 2N2, Canada \\ 3 Public Health Agency of Canada, Winnipeg, MB R3E 3M4, Canada; robbin.lindsay@canada.ca \\ 4 Department of Entomology, University of Manitoba, Winnipeg, MB R3T 2N2, Canada \\ 5 Department of Medical Microbiology, University of Manitoba, Winnipeg, MB R3E 0J9, Canada \\ * Correspondence: Andrea.Kroeker@canada.ca (A.L.K.); Hana.Weingartl@canada.ca (H.W.)
}

Received: 1 November 2018; Accepted: 3 December 2018; Published: 12 December 2018

\begin{abstract}
Rift Valley fever virus (RVFV) is a zoonotic arbovirus of the Phenuiviridae family. Infection causes abortions in pregnant animals, high mortality in neonate animals, and mild to severe symptoms in both people and animals. There is currently an ongoing effort to produce safe and efficacious veterinary vaccines against RVFV in livestock to protect against both primary infection in animals and zoonotic infections in people. To test the efficacy of these vaccines, it is essential to have a reliable challenge model in relevant target species, including ruminants. We evaluated two goat breeds (Nubian and LaMancha), three routes of inoculation (intranasal, mosquito-primed subcutaneous, and subcutaneous) using an infectious dose of $10^{7} \mathrm{pfu} / \mathrm{mL}$, a virus strain from the 2006-2007 Kenyan/Sudan outbreak and compared the effect of using virus stocks produced in either mammalian or mosquito cells. Our results demonstrated that the highest and longest viremia titers were achieved in Nubian goats. The Nubian breed was also efficient at producing clinical signs, consistent viremia (peak viremia: $1.2 \times 10^{3}-1.0 \times 10^{5} \mathrm{pfu} / \mathrm{mL}$ serum), nasal and oral shedding of viral RNA $\left(1.5 \times 10^{1}-8 \times 10^{6}\right.$ genome copies/swab), a systemic infection of tissues, and robust antibody responses regardless of the inoculation route. The Nubian goat breed and a needle-free intranasal inoculation technique could both be utilized in future vaccine and challenge studies. These studies are important for preventing the spread and outbreak of zoonotic viruses like RVFV and are supported by the Canadian-led BSL4ZNet network.
\end{abstract}

Keywords: Rift Valley fever virus; arbovirus; caprine; challenge model; animal vaccine; zoonosis

\section{Introduction}

Rift Valley fever virus (RVFV) is a zoonotic mosquito-borne virus that causes acute infections in ruminants such as goats, cattle, sheep, and camels. Large outbreaks of RVFV have mainly occurred in Sub-Saharan Africa. However, an outbreak outside of the African continent, such as in the Arabian Peninsula in 2001, an imported case in China [1], serological evidence in Turkey [2] and climate changes [3] have raised concerns about the potential spread of the virus to Europe, Asia, and the Americas [4-7].

RVFV outbreaks in livestock are thought to be primarily transmitted by infected mosquitos. Studies have shown that RVFV epidemics typically follow periods of heavy rainfall conducive to large mosquito populations [8-11] as well as the trade and importation of infected animals into 
susceptible regions [12]. In Africa, RVFV is mainly transmitted by the Aedes aegypti mosquito, however, a growing number of studies have made it clear that other mosquito species present in Asia, Europe and North/South America are experimentally competent as RVFV vectors [13-15]. Therefore, if RVFV were to be introduced into other continents and their endemic mosquito populations, it could cause widespread epidemics and could seriously impact the health of human populations and economically important livestock herds.

RVFV infections in livestock are characterized by abortion storms in pregnant ruminants and high rates of mortality in young sheep, goats, cattle, and camels [16,17]. In contrast, human infections are thought to occur either through mosquito bites or via aerosol transmission from the blood of infected animals [17,18]. For example, the 1977-1978 outbreak in Egypt was identified as a mosquito-transmitted outbreak while the 2009-2011 outbreak in South Africa was primarily an aerosol-transmitted epidemic from exposure to the blood of ruminants during slaughter [18-20]; not surprisingly, veterinarians and livestock workers who were in close contact with infected animals were identified as most at risk [21]. Human infection can result in subclinical to severe illness that in some cases can progress to retinal vasculitis, resulting in blindness, encephalitis, and fatal hepatitis with hemorrhagic fever [22]. While reported human case fatality rates are generally low, higher fatality rates (20-40\%) were observed in the Kenyan outbreak of 2007-2008 [23] and in Mauritania in 2012 [24]. Therefore, vaccination of livestock against RVFV is an important consideration for both livestock and their associated workers.

There is currently an ongoing effort to produce safe and efficacious vaccines against RVFV in livestock [25-32] as well as reliable challenge models for testing these vaccines. Several groups have developed challenge models for RVFV in cattle [33] and sheep [34,35], and we recently published a challenge model in four month old goats $[35,36]$. These initial studies have identified important factors of pathogenesis such as infectious dose and the use of insect-derived virus compared to mammalian-derived virus [35]. In addition, several interesting studies have also demonstrated that mosquito saliva can modulate RVFV infection in mice [37]. Interestingly, different routes of transmission have also been studied; for example, aerosol exposure to RVFV led to different disease kinetics and outcomes in mice [38] and non-human primates [39,40] and sheep have been documented to become infected through direct contact [41]. Furthermore, RVFV has been shown to be highly dependent on the viral strain, animal species, breed, and age. Therefore, our goal in this study was to explore how some these factors affected the pathogenicity of our goat model and whether they could be utilized in future vaccine efficacy trials.

\section{Materials \& Methods}

\subsection{Ethics Statement}

All animal experiments were carried out in the enhanced biosafety level 3 (BSL3) facility at the National Centre for Foreign Animal Disease (NCFAD) in Winnipeg, Manitoba. All protocols for animal use were approved on 1 March 2017 under the animal use document number C-17-002 at the Canadian Science Centre for Human and Animal Health (CSCHAH) in Winnipeg, Manitoba by the Animal Care Committee. Care was taken to minimize animal suffering and to follow the Canadian Council on Animal Care guidelines for animal manipulations.

\subsection{Cells}

Mosquito C6/36 cells (ATCC, Manassas, VA, USA) were grown and infected in 1:1 EMEM and ESF-921 (Expression Systems, Davis, CA USA) supplemented with 10\% fetal bovine serum (FBS) (Hyclone/Fisher Scientific, Ottawa, ON, Canada) and 1\% L-glutamine and maintained at $28{ }^{\circ} \mathrm{C}$ without $\mathrm{CO}_{2}$. Mammalian Vero E6 (VE6) (ATCC) cells were grown and infected in DMEM (Gibco/Fisher Scientific, Ottawa, ON, Canada) supplemented with $10 \%$ FBS and maintained at $37{ }^{\circ} \mathrm{C}$ with $95 \%$ relative humidity and $5 \% \mathrm{CO}_{2}$. 


\subsection{Virus Production and Titration}

A virus isolate from the 2006-2007 Kenyan outbreak (Genbank \#MH175203, MH175204, MH175205) was blindly passaged in VE6 cells four times until CPE was visible (titer $2 \times 10^{5} \mathrm{pfu} / \mathrm{mL}$ ). Thereafter, virus was alternatively passaged between VE6 and C6/36 cells [42] and the collected virus was titrated on VE6 cells with a plaque assay to determine virus concentration: At passage 5 the virus was amplified in C6/36 cells $\left(1.4 \times 10^{5} \mathrm{pfu} / \mathrm{mL}\right)$; at passage 6 the virus was amplified in VE6 cells $\left(2.3 \times 10^{6} \mathrm{pfu} / \mathrm{mL}\right)$; at passage 7 the virus amplified in C6/36 cells $\left(1 \times 10^{7} \mathrm{pfu} / \mathrm{mL}\right)$; and at passage 8 the virus was amplified in VE6 cells $\left(1.4 \times 10^{7} \mathrm{pfu} / \mathrm{mL}\right)$. The goats were then infected using passage 7 C6/36-derived virus or passage 8 VE6-derived virus.

\subsection{Genome Sequencing}

RNA was converted to cDNA using the Superscript IV First Strand Synthesis Module (Invitrogen/Fisher Scientific, Ottawa, ON, Canada) according to the manufacturer's specifications except for the following modifications: Eight gene specific primers $(10 \mu \mathrm{M} ; 0.25 \mu \mathrm{L}$ each) [43] were used to selectively enrich for RVFV RNA, and a total of $10 \mu \mathrm{L}$ of RNA was added to the reaction. Second strand synthesis was carried out using the NEBNext mRNA Second Strand Synthesis Module (New England Biolabs, Winnipeg, MB, Canada) according to the manufacturer's specifications. The double-stranded cDNA was purified using the QIAquick PCR Purification Kit (Qiagen, Toronto, ON, Canada) according to the manufacturer's specifications and eluted in $20 \mu \mathrm{L}$ of nuclease-free water. A volume of $2 \mu \mathrm{L}$ of purified double-stranded cDNA from each sample was quantified on the Qubit 3.0 fluorometer (ThermoFisher Scientific, Burlington, ON, Canada) using the dsDNA High Sensitivity Kit (ThermoFisher Scientific). The samples were diluted to $0.2 \mathrm{ng} / \mu \mathrm{L}$ in nuclease-free water and a total of $5 \mu \mathrm{L}$ of diluted material was used as input to generate sequencing libraries using the Nextera XT Library Preparation Kit (Illumina, San Diego, CA, USA), then pooled with other libraries before sequencing on an Illumina MiSeq platform using a V2 300-cycle $(2 \times 150$ bp reads) cartridge (Illumina) and Micro flow cell (Illumina).

\subsubsection{Sanger Sequencing}

Sanger sequencing was used to sequence a short GC-rich area located in the intergenic region of the $S$ segment that had no MiSeq reads mapping to the reference for all samples tested. Briefly, samples were amplified by singleplex PCR using the SuperScript III One-Step RT-PCR System with Platinum Taq DNA Polymerase (Invitrogen) and in-house designed primers (Forward: 5'-CTAGAGGACTCCTTTGTTGG-3', Reverse: 5'-CTTGAAAGCCTTTGGACTTG-3') to generate a $505 \mathrm{bp}$ amplicon spanning the intergenic region of the $\mathrm{S}$ segment. Thermal cycling was performed for $30 \mathrm{~min}$ at $47^{\circ} \mathrm{C}$ for reverse transcription, $3 \mathrm{~min}$ at $94{ }^{\circ} \mathrm{C}$ for initial denaturation, followed by 40 cycles of $15 \mathrm{~s}$ at $94^{\circ} \mathrm{C}, 30 \mathrm{~s} 47^{\circ} \mathrm{C}$, and $1 \mathrm{~min}$ at $68^{\circ} \mathrm{C}$ and a final extension for $5 \mathrm{~min}$ at $68^{\circ} \mathrm{C}$. Amplicons were sequenced using BigDye Terminator v3.1 technology on an ABI 3130xl Genetic Analyzer system (Applied Biosystems/Fisher Scientific, Ottawa, ON, Canada).

\subsubsection{Bioinformatic Sequencing Analysis}

Read quality of data from the MiSeq was first visualized in FastQC (v0.11.5) (omicX, Le Petit-Quevilly, France), followed by quality filtering and trimming using Trimmomatic (v0.36 with headcrop 20 and sliding window 4:20) (RWTH Aachen University, Aachen, Germany) and de novo assembly using SPAdes assembler (v3.11.1 in metagenomic mode with default settings) (St. Petersburg State University, St. Petersburg, Russia). The resulting assembled contigs were then characterized with blastn to determine their closest match within the $\mathrm{nr} / \mathrm{nt}$ database. The closest full-length sequence match for each of the three viral gene segments was then used to perform a reference assembly with the raw data (Geneious v9.1.5 on Low Sensitivity/Fastest setting) (Biomatters, Auckland, New Zealand). Finally, for each sample 
MiSeq and Sanger sequencing data were combined to generate a consensus sequence for each segment (Geneious v9.1.5).

\subsubsection{Phylogenetic Analysis}

The evolutionary history of the RVFV UAP strain was inferred by using the Maximum Likelihood method based on the JTT matrix-based model [44]. The bootstrap consensus tree inferred from 1000 replicates [45] is taken to represent the evolutionary history of the taxa analyzed [45]. Branches corresponding to partitions reproduced in less than $50 \%$ bootstrap replicates are collapsed. The percentage of replicate trees in which the associated taxa clustered together in the bootstrap test (1000 replicates) is shown next to the branches [45]. Initial trees for the heuristic search were obtained automatically by applying Neighbor-Join and BioNJ algorithms to a matrix of pairwise distances estimated using a JTT model, and then selecting the topology with superior log likelihood value. The analysis involved 10 amino acid sequences. There were a total of 2128 positions in the final dataset. Evolutionary analyses were conducted in MEGA7 [46].

\subsection{Goat Inoculation}

Twenty-nine healthy 4 month old Nubian or LaMancha goats were obtained from breeders in Manitoba, Canada and were allowed 7 days to acclimatize to BSL3+ containment at NCFAD, during which they were monitored daily for any signs of disease. After acclimatization, the goats were divided into groups of 2-4 and housed in separate cubicles.

\subsubsection{Subcutaneous (Nubian and LaMancha Goats)}

A group of Nubian and LaMancha goats were inoculated subcutaneously with $10^{7}$ pfu in $1 \mathrm{~mL}$ insect-derived RVFV. A group of controls were also inoculated subcutaneously with PBS.

\subsubsection{Mosquito-Primed Subcutaneous (Nubian Goats Only)}

A $50 \mathrm{~mL}$ Falcon tube was filled with fifty naïve Aedes aegyti mosquitos and the open end was covered with a fine mesh. The mesh side was then placed on a shaved surface on the goat's necks for $20 \mathrm{~min}$ so that the mosquitos could feed. This same surface area was then subsequently inoculated subcutaneously with $10^{7}$ pfu in $1 \mathrm{~mL}$ insect-derived RVFV.

\subsubsection{Intranasal (Nubian and LaMancha Goats)}

One group of Nubian and one group of LaMancha goats were each inoculated intranasally with $10^{7} \mathrm{pfu}$ insect-derived RVFV. A second group of LaMancha goats was inoculated intranasally with $10^{7}$ pfu mammalian-derived RVFV. Each goat was given a total of $1 \mathrm{~mL}$ virus using a $2 \mathrm{~mL}$ syringe, with half given in each nostril.

\subsection{Clinical Scoring, Goat Sampling E Tissue Collection}

\subsubsection{Scoring}

All goats were monitored for clinical symptoms and rectal temperatures daily. We then calculated a clinical score for the group based on the following characteristics: General appearance (normal $=0$, mild disease $=1$, disease $=2$ ); fever in any animal (temperature $<41=0$, temperature $\geq 41=1$ ); disposition (bright/alert/responsive $=0$, quiet/alert $/$ responsive $=1$, depressed $=2$ ); eating habits (normal $=0$, less than normal $=1$, very little $/$ nothing $=2)$, drinking habits (normal $=0$, nothing $=2$ ), and consistency of feces (normal $=0$, clumped / soft $=1$, diarrhea $=2$ ). Using our scale, a maximum score of 11 was possible and generally included only mild signs of disease; however, not eating or drinking for more than one day was considered an endpoint. 


\subsubsection{Sampling}

Blood for serum isolation and oral and nasal swabs were collected prior to infection and daily for the first 7 days post infection. Blood, oral and nasal swabs were also collected on days 14, 21, and 28 post infection. Serum samples and swabs were stored at $-70^{\circ} \mathrm{C}$.

\subsubsection{Tissues}

Tissues from infected animals were collected at day $1(n=1)$, day $7(n=1)$ and day $28(n=2)$ post infection and tissues from uninfected control goats were all collected on day 28 . Tissues were either placed in $10 \%$ formalin for downstream tissue sectioning or processed as 10\% homogenates in DMEM (Gibco) for RNA extraction and virus isolation.

\subsection{Virus Isolation by Plaque Assay}

Serial dilutions of serum, nasal swabs and oral swabs were used to infect confluent monolayers of VE6 cells for $1 \mathrm{~h}$. The virus was then removed and the cells were overlayed with $1.75 \%$ carboxymethylcellulose (CMC, MilliporeSigma, Oakville, ON, Canada). After 3 days the cells were formalin-fixed and stained with $0.5 \%$ crystal violet (MilliporeSigma) to visualize and count plaques.

\subsection{RNA Isolation and RT-PCR}

RVFV RNA was extracted from serum using the TriPure Isolation Reagent (Roche, Laval, QC, Canada) according to the manufacturer's instructions. Purified RNA was stored at $-70{ }^{\circ} \mathrm{C}$. We detected viral RNA with a one-tube real-time polymerase chain reaction (RT-PCR) mix (Rotor-Gene Dual Probe kit, Qiagen) [47] as per the manufacturer's instructions and ran the samples on the Rotor Gene PCR machine with the following conditions: $30 \mathrm{~min}$ at $50^{\circ} \mathrm{C}, 2 \mathrm{~min}$ at $95^{\circ} \mathrm{C}$ and 45 cycles of $15 \mathrm{~s}$ at $95^{\circ} \mathrm{C}$, and $30 \mathrm{~s}$ at $60^{\circ} \mathrm{C}$. Primers (Invitrogen) and probe (Biosearch Tech, Petaluma, CA, USA) targeted nucleotides 2912 to 3001 for the RVFV L gene segment [5]. All Ct values were plotted on a standard curve using a DNA plasmid containing the targeted RVFV L gene segment (GenScript, Piscataway, NJ, USA) and quantified.

\subsection{In Situ Hybridization of RVFV-Probe in Tissues}

Five-micron paraffin-embedded formalin fixed tissue sections were cut, air-dried, and melted onto charged slides in a $60^{\circ} \mathrm{C}$ oven. The slides were then cleared and hydrated in xylene and $100 \%$ ethanol, and then air-dried. The sections were quenched for $10 \mathrm{~min}$ in aqueous $\mathrm{H}_{2} \mathrm{O}_{2}$, boiled in target retrieval solution for $15 \mathrm{~min}$, rinsed in $100 \%$ ethanol and air-dried again. A final treatment of protease plus enzyme for $15 \mathrm{~min}$ at $40{ }^{\circ} \mathrm{C}$ was applied. Next, the probe (V-RVFV-ZH501-NP, from Advanced Cell Diagnostics, Newark, CA, USA) was applied and incubated at $40{ }^{\circ} \mathrm{C}$ for $2 \mathrm{~h}$. The hybridization amplification steps (AMP 1-6) were applied to the slides for the recommended times and temperatures as per the manual for the RNAscope ${ }^{\circledR} 2.5 \mathrm{HD}$ Detection Reagent-the Red kit (Advanced Cell Diagnostics). The signal was then visualized with Fast Red after which the slides were counterstained with Gill's hematoxylin, dried, cleared and cover-slipped.

\subsection{Neutralizing Antibody Detection (PRNT)}

The presence of neutralizing antibodies to RVFV was determined by a plaque reduction neutralization test (PRNT). Serial 2-fold dilutions of serum were prepared in PBS and incubated with an equal volume of insect-derived RVFV for $1 \mathrm{~h}$ at room temperature. Thereafter, $75 \mu \mathrm{L}$ of the sera-virus mixture was adsorbed to confluent monolayers of VeroE6 cells in 48-well plates in triplicate for $1 \mathrm{~h}$ at $37{ }^{\circ} \mathrm{C}, 5 \% \mathrm{CO}_{2}$, and $95 \%$ relative humidity. A carboxymethylcellulose (MilliporeSigma) overlay was then added to all wells and plates were further incubated at $37{ }^{\circ} \mathrm{C}, 5 \% \mathrm{CO}_{2}$, and $95 \%$ relative humidity. At 4 days post infection, the cells were fixed with $10 \%$ formalin, stained with $0.5 \%$ 
crystal violet, and plaques were counted. The reciprocal of the highest serum dilution that reduced plaques by $70 \% \mathrm{CPE}$ was read as the antibody-PRNT 70 titre for that sample.

\section{Results}

\subsection{Phylogenetic Analysis of a 2006-2007 Strain of the Kenya-UAP RVFV Strain}

The RVFV strain used in this study was sequenced and compared to other published RVFV sequences. Greater than $99 \%$ coverage of the reference $\mathrm{ZH}-501$ strain and an average read depth of 400-2000 reads per nucleotide was achieved (Figure 1A-C). We also directly compared sequences of our isolate to the Ken-128-b strain used in another study [33,34], as well as the commonly used ZH-501 strain. Our strain matched these with 96.6-99.18\% identity at the amino acid level (Figure 1E) and with 94.6-97.75\% at the nucleotide level (Figure 1D). We found this sequence homology to be of significance, in that any differences between this study and our previous study with Boer goats and the ZH-501 strain is likely more attributable to the goat breed or the inoculation method than the virus strain. In addition, a phylogenetic comparison demonstrated that the $\mathrm{L}, \mathrm{M}$, and $\mathrm{S}$ segments all clustered with other strains isolated during the 2006-2007 outbreak from Sudan or Kenya (Figure 2A-C, respectively).
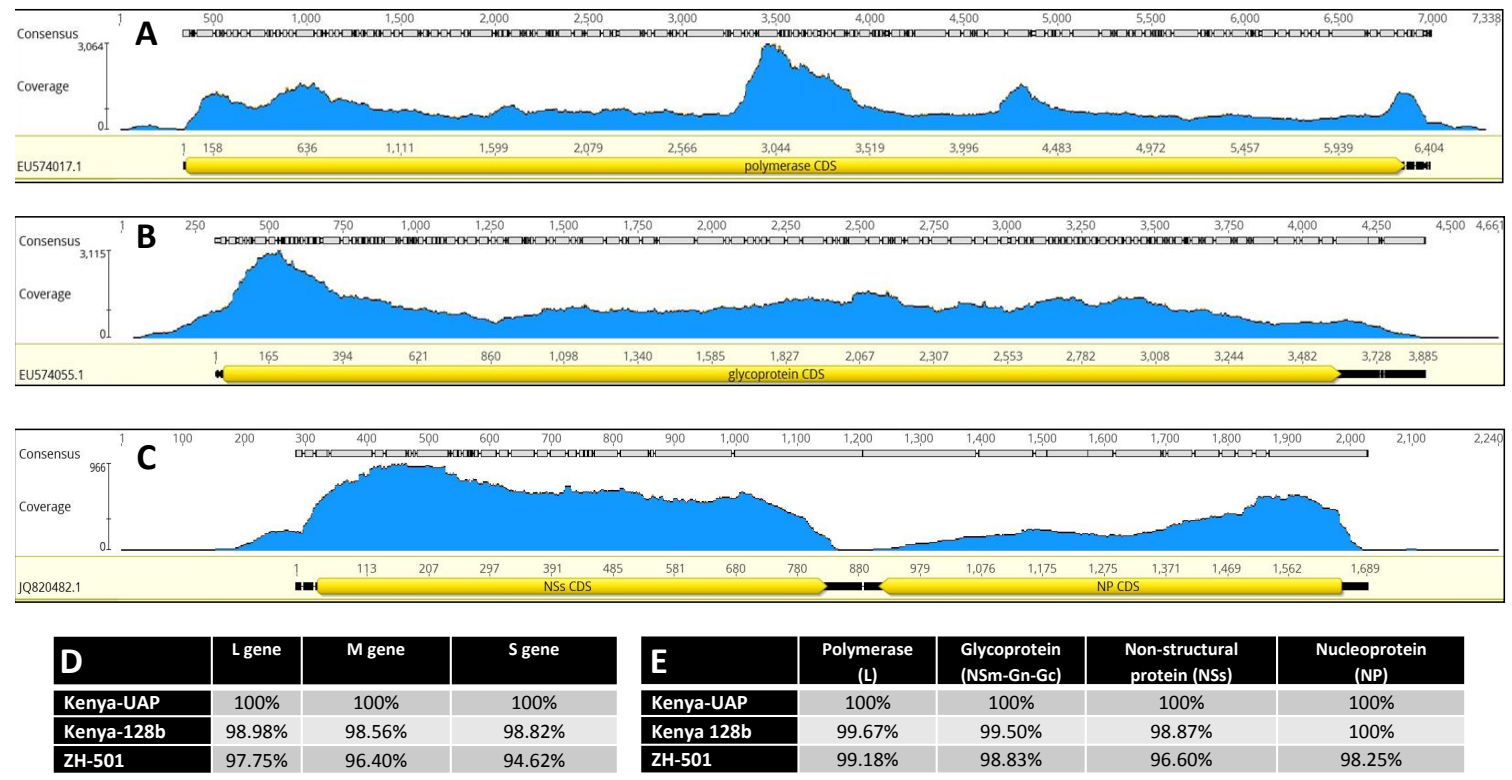

Figure 1. Sequence of RVFV strain UAP. Next generation sequencing was used to sequence the three genome segments of RVFV: L (A), M (B), and S (C). In each graph, the $y$-axis indicates the number of reads and $x$-axis represents the coverage over the length of the gene in base pairs. The nucleotide (D) and corresponding amino acid (E) sequences of the three RVFV genome segments of UAP were aligned with ZH-501 and Kenya-128-b RVFV strains; results of \% homology between the strains are presented for each genome segment.

\subsection{Experimental Design}

We compared three different routes of RVFV infection in the Nubian and LaMancha goat breeds (Figure 2A,B). Five groups were infected with virus derived from the C6/36 (C6) mosquito cell line and one group was infected with virus grown in the Vero E6 (VE6) mammalian cell line. The subcutaneous (SC) infection method is widely used in RVFV infection models $[33-35,39,47]$ and allows the primary target cells, dermal dendritic cells [48,49], to be infected. Importantly, the subcutaneous group allowed our 2006-2007 RVFV strain to be compared to many other published studies. Our second route of inoculation consisted of a mosquito-primed subcutaneous infection. Several interesting studies in mice have demonstrated that mosquito saliva can modulate RVFV infection [37] as well as other arbovirus infections [50-52] and we sought to evaluate this effect in a large animal model. Thirdly, several groups 
were infected intranasally (IN) as a few studies have shown that aerosol exposure to RVFV could lead to different disease kinetics and outcomes in mice [38] and non-human primates [39,40].
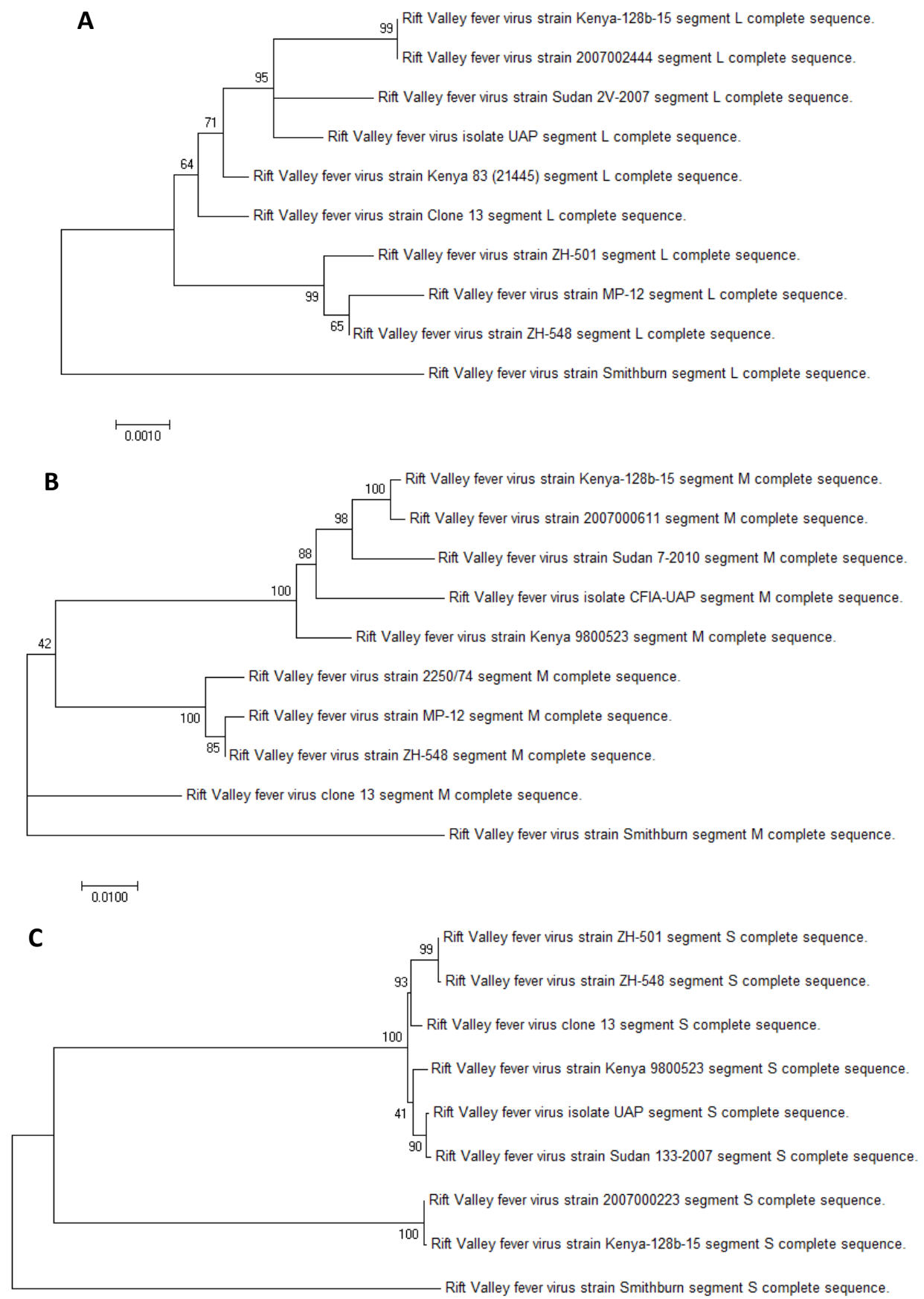

0.10

Figure 2. Phylogenetic analysis of RVFV strain UAP A phylogenetic analysis of the RVFV strain UAP using the Maximum-Likelihood Model was performed using MEGA7 software for each of the three RVFV genome segments: L (A), M (B), and S (C).

\subsection{Clinical Signs and Gross Pathology}

Inoculation of both the Nubian and LaMancha goats with RVFV resulted in mild clinical signs in all of the groups during the first week of infection. In the Nubian goats, the subcutaneous group reached the highest clinical score (two-five out of 11), the mosquito-primed group was intermediate 
(one-three out of 11) and the intranasal was the lowest (one out of 11) (Figure 3C). The LaMancha goats had higher clinical scores overall with the intranasal groups reaching the highest scores (two-seven out of 11) and the subcutaneous exhibiting the lowest score (two-five out of 11) (Figure 3D). The extent of observed clinical signs included a mild fever (Nubians Figure 3E; LaMancha Figure 3F), clumped stool, diminished eating, and mild depression.
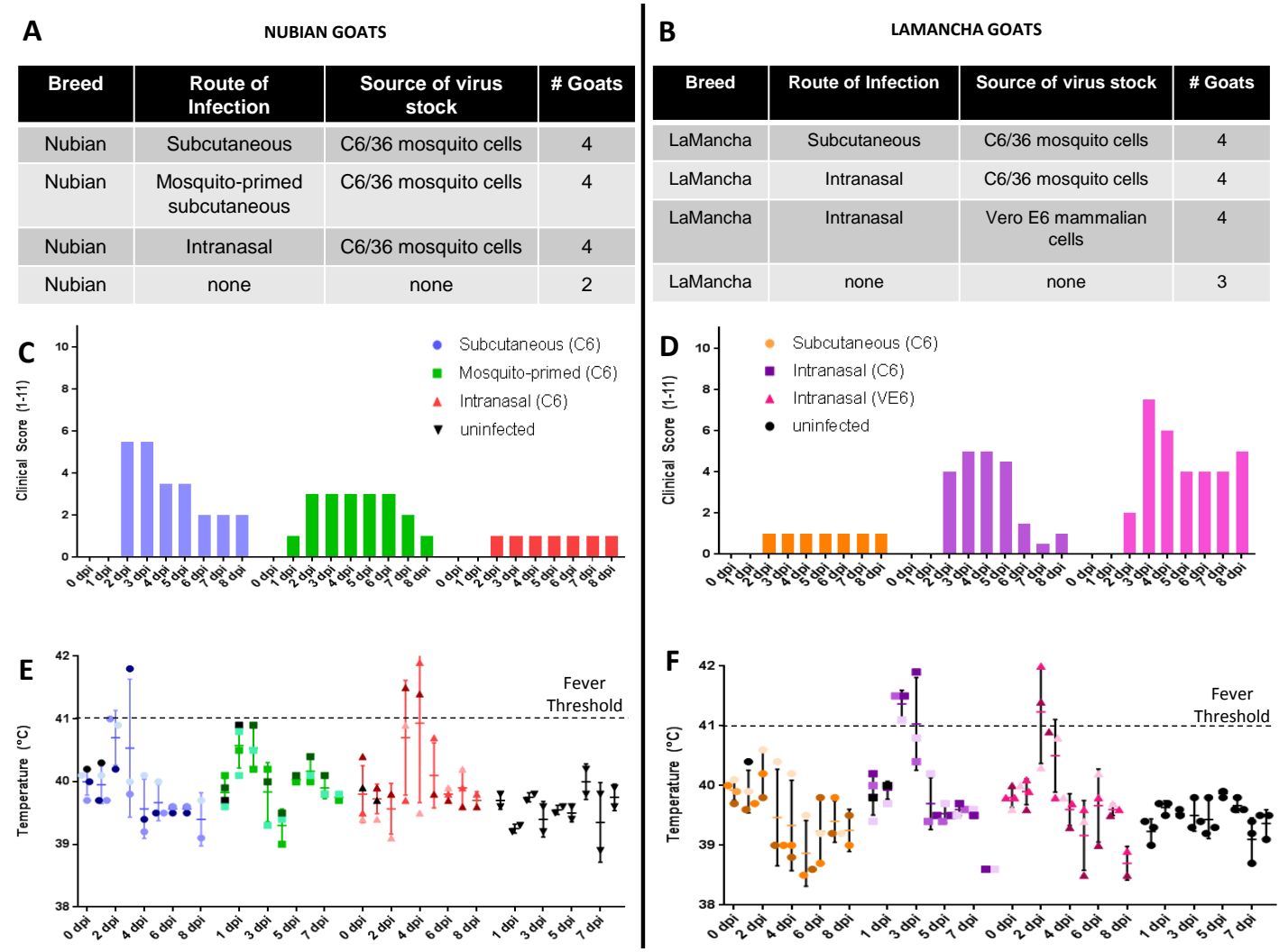

Figure 3. Experimental design and clinical signs. The differences between and number of animals in the experimental groups are summarized for the Nubian (A) and LaMancha (B) goats. Nubian (C) and LaMancha (D) goats were examined daily for signs of illness and each experimental group was collectively given a clinical score between 0 and 11 . Rectal temperatures were taken and recorded daily for the Nubian (E) and LaMancha (F) goats. The threshold for fever was considered to be a temperature of $41^{\circ} \mathrm{C}$ or higher. Temperature values are shown for individual goats $(n=4$ at $0-1 \mathrm{dpi} ; n=3$ at $2-7 \mathrm{dpi}$; and $n=2$ at $8 \mathrm{dpi}$ ); the horizontal line represents the average for the group; the vertical line represents the standard deviation for the group. C6 refers to virus that was grown in C6/36 mosquito cells; VE6 refers to virus that was grown in VE6 mammalian cells. The Nubian and LaMancha uninfected groups received an injection of PBS but no virus.

In the Nubian goats all signs generally resolved by eight-10 dpi. In the LaMancha goats, most clinical signs improved at eight-10 dpi, but did not resolve completely (data not shown). However, ringworm was detected in all LaMancha goats at 14 dpi and likely contributed to the continued presence of mild clinical signs, primarily clumped stool. We postulated that the LaMancha goats had arrived with a latent ringworm infection that may have become apparent during the experiment. Finally, we performed necropsies and collected tissues at one, seven, and $28 \mathrm{dpi}$. We did not detect any gross pathological changes at these time points.

\subsection{Viremia, Shedding and Tissue Viral Load}

All routes of inoculation in both Nubian and LaMancha goats led to infection and consistent viremia, where viremia was detectable for two-four days by RT-PCR (Figure 4A-F, triangles) and for two 
days by virus isolation (Figure 4A-F, circles). Interestingly, while subcutaneous and mosquito-primed subcutaneous routes led to viremia already on day one post infection, viremia in the intranasal group was delayed until day two or three post infection and correlated with a delayed fever (Figure 3E,F). Clinical signs generally appeared a day after the appearance of viremia and lasted until several days after viremia had been cleared. Clinical scores did not necessarily correlate with the quantity of virus detected though. In the LaMancha goats, a similar trend was seen with the mosquito-derived virus groups; however, viremia tended to be a day shorter than in the Nubian goats (Figure 4D-F). Of all the groups, the highest viremia peak titer reached was $10^{5} \mathrm{pfu} / \mathrm{mL}$ in the Nubian intranasal group.
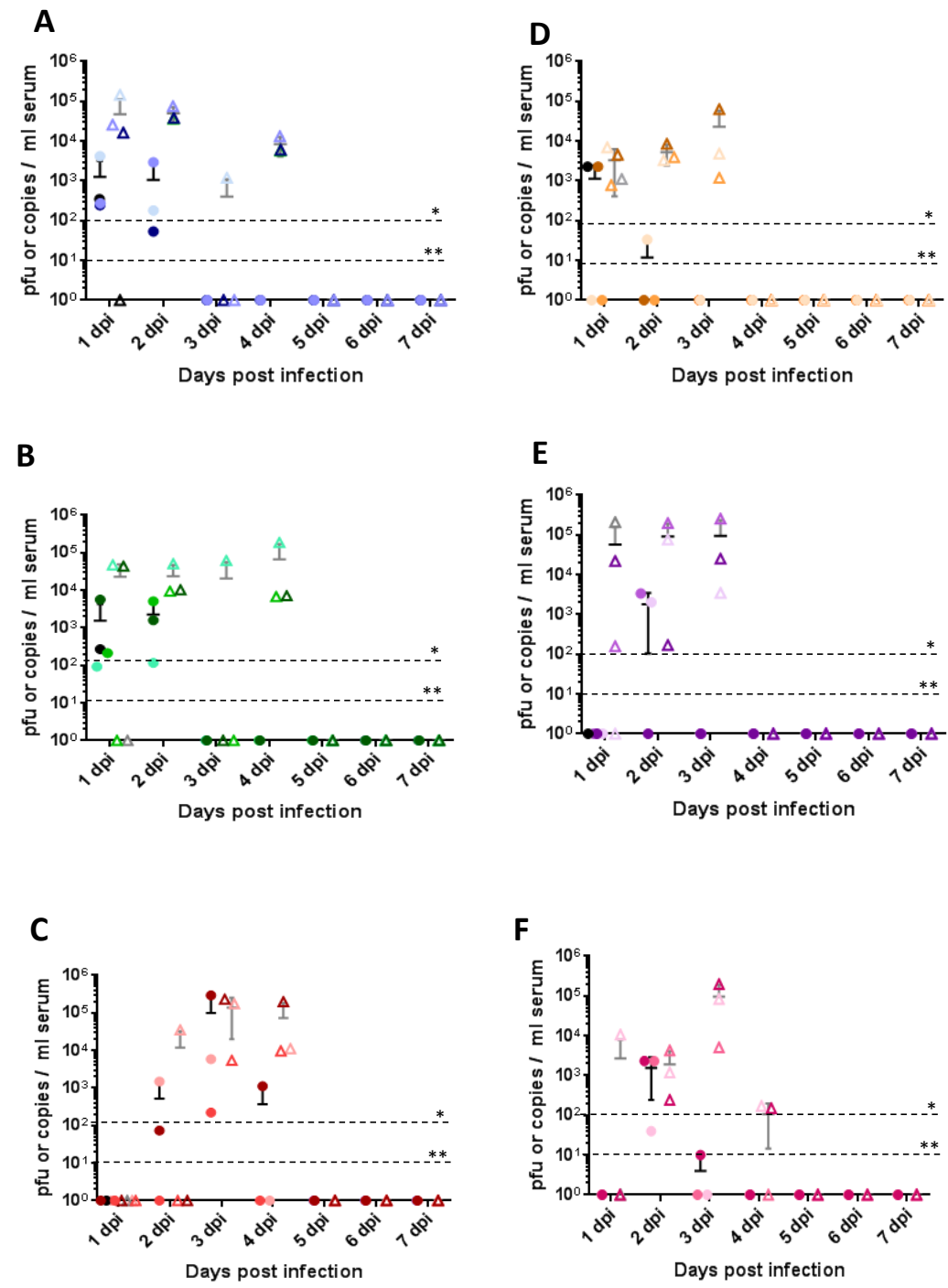

Figure 4. Quantification of viremia. (A-C) Quantification of RVFV viremia in Nubian goats after subcutaneous infection (A), mosquito-primed subcutaneous infection (B), and intranasal infection (C). (D-F) Quantification of RVFV viremia in LaMancha goats after subcutaneous infection (D), intranasal infection with mosquito cell-derived virus (E), and intranasal infection with mammalian cell-derived virus (F). Triangles indicate the presence of viral RNA as measured by RT-PCR; circles indicate the presence of infectious virus as measured by plaque assay. Values are shown for individual goats $(n=4$ on day $1 ; n=3$ on days $2-7$ ); the horizontal line represents the average for the group; the vertical line represents the standard deviation for the group. C6 refers to virus that was grown in C6/36 mosquito cells; VE6 refers to virus that was grown in VE6 mammalian cells. The PCR and plaque detection thresholds are indicated. Dpi: days post infection. ${ }^{*}$ threshold for RNA detection; ${ }^{* *}$ threshold for plaque detection. 
All of the Nubian goats had nasal (Figure 5A-C) and oral (Figure 5D-F) shedding of viral RNA $\left(10^{3}-10^{7}\right.$ copies/swab) at 2-6 dpi; however no infectious virus was detected. In contrast, neither viral RNA nor infectious virus was found in nasal or oral swabs from any of the LaMancha goats (data not shown).
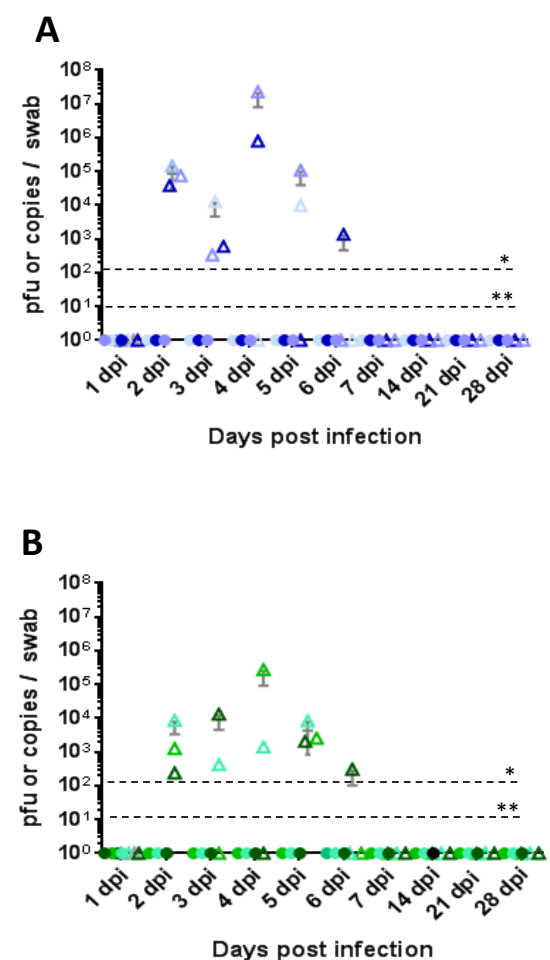

C

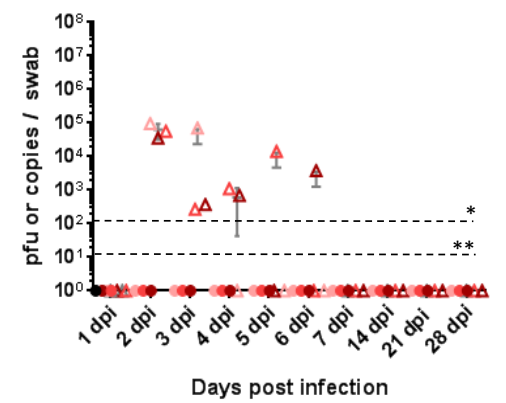

D

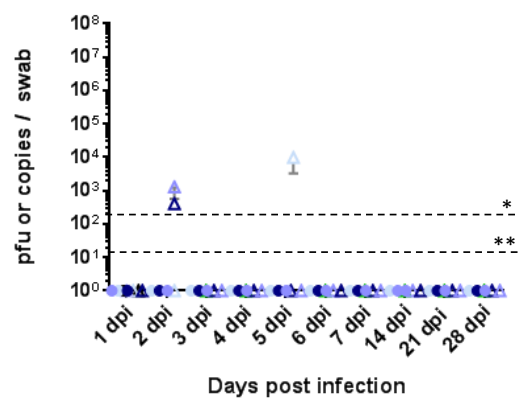

E

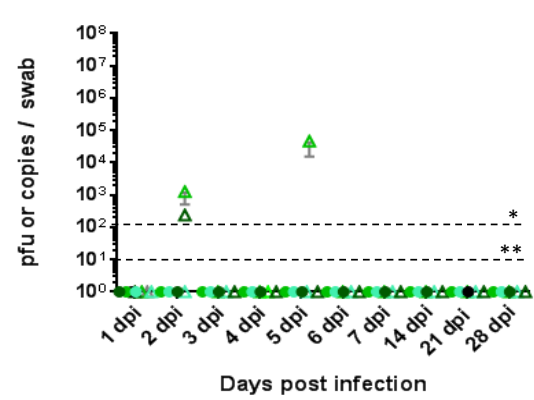

$\mathbf{F}$

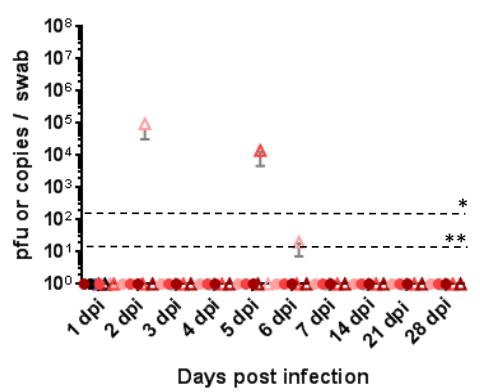

Figure 5. Oral and nasal shedding. (A-C) Quantification of RVFV in nasal swabs in Nubian goats after subcutaneous infection (A), mosquito-primed subcutaneous infection (B), and intranasal infection (C). (D-F) Quantification of RVFV in oral swabs in Nubian goats after subcutaneous infection (D), mosquito-primed subcutaneous infection (E), and intranasal infection (F). All LaMancha swabs were negative for virus and data is not shown. Triangles indicate the presence of viral RNA as measured by RT-PCR; circles indicate the presence of infectious virus as measured by plaque assay. Values are shown for individual goats ( $n=4$ on day $1 ; n=3$ on days $2-7$; and $n=2$ on days $14-28$ ); the horizontal line represents the average for the group; the vertical line represents the standard deviation for the group. C6 refers to virus that was grown in C6/36 mosquito cells; VE6 refers to virus that was grown in VE6 mammalian cells. The PCR and plaque detection thresholds are indicated. Dpi: Days post infection. * threshold for RNA detection; ${ }^{* *}$ threshold for plaque detection.

In the Nubian goats, all routes of inoculation also led to a systemic spread of the virus into the tissues. While no infectious virus was isolated at our time points, viral RNA was detectable in the 
spleen, liver, lymph nodes, and a variety of brain tissues (Figure 6). Our first time points consisted of one dpi to catch early localization of the virus in vivo. Indeed, we detected viral RNA in the trigeminal nerve in the intranasally infected group and in the spleen in the mosquito-primed-SQ group (Figure 5A). By seven dpi, the mesenteric, prescapular, and retropharyngeal lymph nodes were generally positive for viral RNA in all groups (Figure 6) $\left(10^{2}-10^{6}\right.$ copies/g tissue) and a few remained positive at $28 \mathrm{dpi}$ (Figure 6). The spleen was positive for the duration of the experiment in the mosquito-primed group $\left(10^{2}-10^{4}\right.$ copies/g tissue), but only appeared by day 28 in the intranasal group (Figure 6) and not at all in the subcutaneous group. In contrast, viral RNA was not detected in the liver except at day 28 for the mosquito-primed group (Figure 6). Virus had begun to invade brain tissue in the subcutaneous and mosquito-primed groups by seven dpi (Figure 6), and in the intranasal group by $28 \mathrm{dpi}$. Notably, virus was particularly widespread throughout all the brain tissues tested in the mosquito-primed-SC group at 28 dpi (Figure 6). In contrast, neither viral RNA nor infectious virus was found in any tissues in the LaMancha goats at one, seven, or 28 dpi (data not shown).

Subcutaneous (C6) Mosquito-primed (C6)

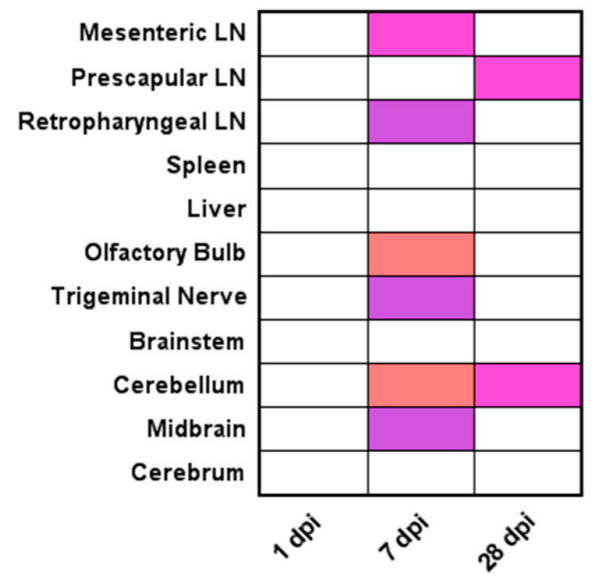

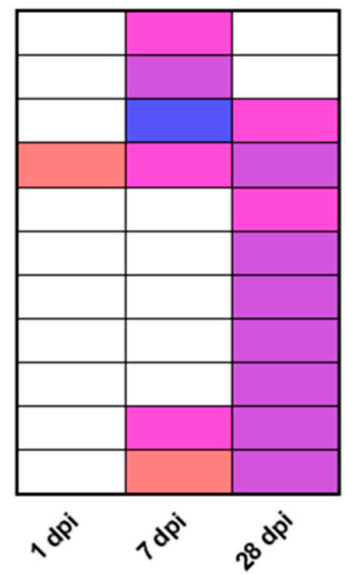

Intranasal (C6)

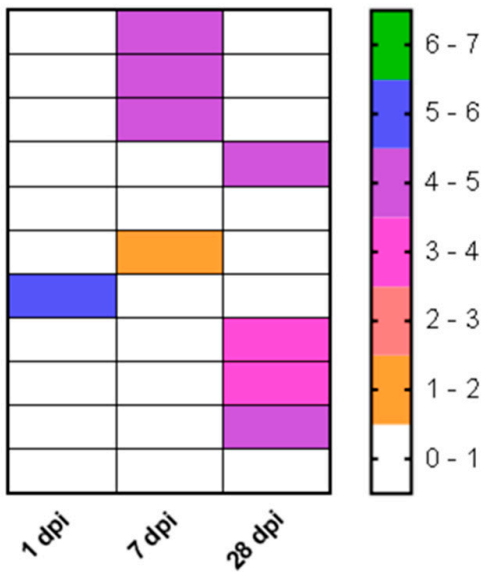

Figure 6. Viral load in tissues. Quantification of RVFV in tissues in Nubian goats at 1 dpi $(n=1), 7$ dpi $(n=1)$, and $28 \mathrm{dpi}(n=2)$. Only data for the detection of viral RNA by RT-PCR is shown; virus isolations for all tissues were negative. All LaMancha tissues were negative for virus and data is not shown. Dpi:

Days post infection. C6 refers to virus that was grown in C6/36 mosquito cells. LN: Lymph node.

\subsection{In-Situ Hybridization for RVFV}

We also confirmed the presence of virus in selected tissues using in-situ hybridization against the RVFV nucleoprotein (NP) sequence. For example, the spleen had positive staining at day 28 in all groups (Figure 7B-D), and at day seven in the mosquito group (data not shown, but it is similar to Figure $7 \mathrm{~B}, \mathrm{C})$. In contrast, the Nubian subcutaneous and intranasal groups had no staining at day seven and none of the Nubian groups had staining at day one (Figure 7A is a representative image of negative staining in the spleen). Any positive staining was scattered only throughout the spleen follicles in the white pulp and ranged from weak (Figure 7B,C) to strong staining patterns (Figure 7D). Liver samples from the subcutaneous and mosquito-primed groups on day 28 were negative for virus staining. Similarly, the trigeminal nerve was negative for virus straining from the intranasal group on day one, from the subcutaneous group on day 7 and from the mosquito-primed group on day 7.

\subsection{Neutralizing Antibodies}

We detected neutralizing antibodies against RVFV in both Nubian (Figure 8A) and LaMancha (Figure 8B) goats starting at four-five days post infection. In both goat breeds, all groups displayed similar titers and kinetics with a peak at 21 days post infection and peak titers of $1 / 1280$ to $1 / 5120$. 

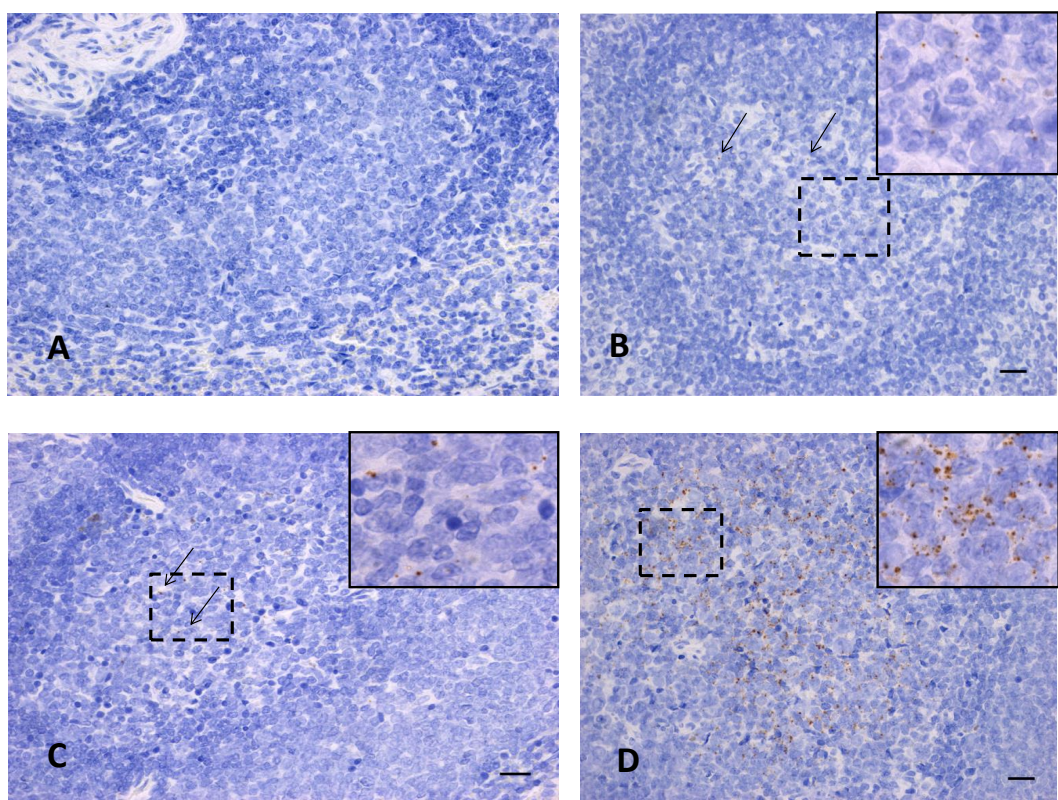

Figure 7. In situ hybridization for RVFV in tissues. In-situ hybridization staining for RVFV in spleen tissues from Nubian goats. (A) subcutaneous infection at 7 dpi $(n=1)$, (B) subcutaneous infection at $28 \mathrm{dpi}(n=2),(\mathbf{C})$ mosquito-primed subcutaneous infection at $28 \mathrm{dpi}(n=2)$, and (D) intranasal infection at 28 dpi $(n=2)$. The large images are taken at $40 \times$ magnification and arrows indicate individual dots in the slides where weak staining is present. The inserted panels in (B-D) are taken at $100 \times$ magnification to help visualize an area of positive staining, as shown within the dotted lines.

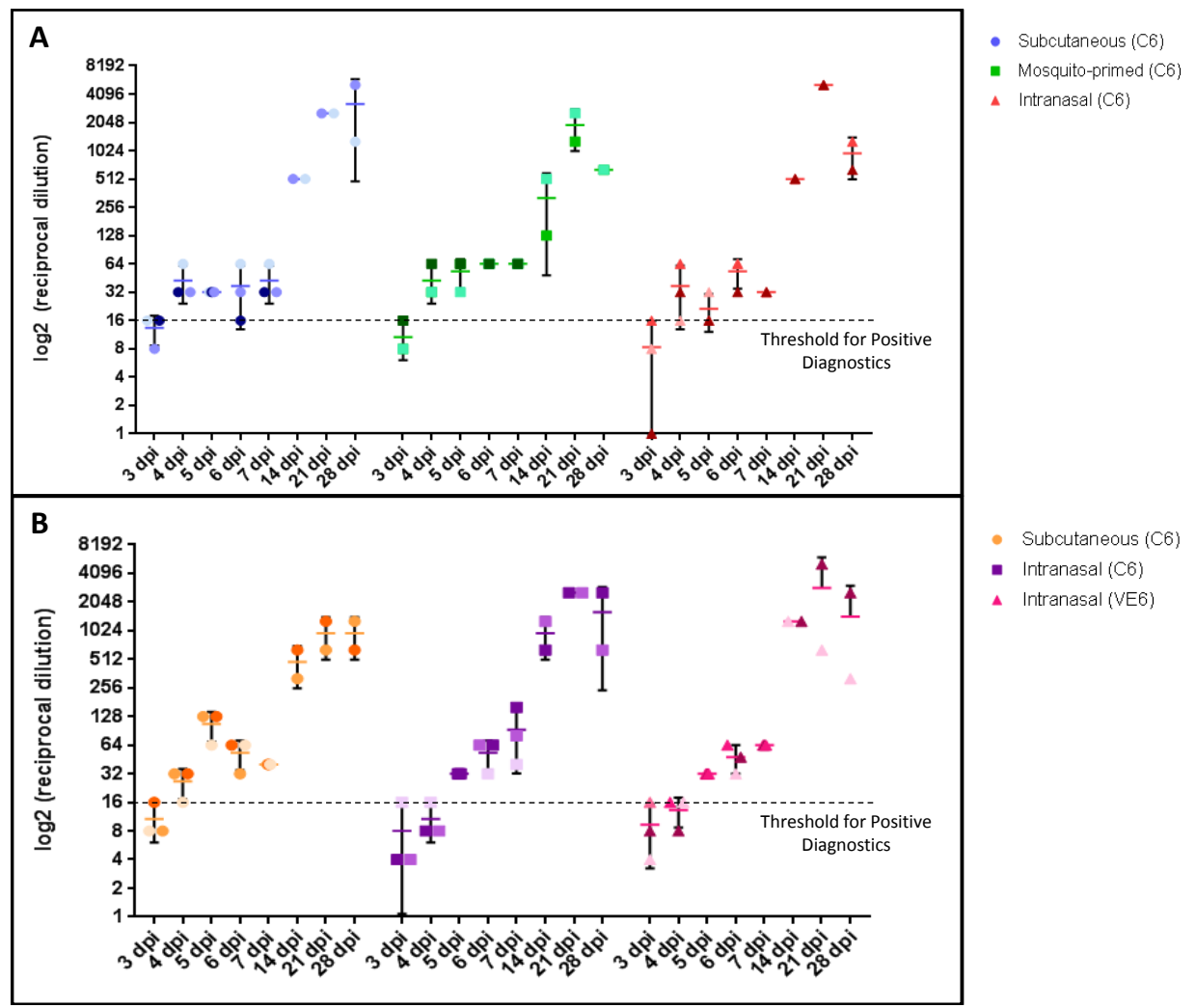

Figure 8. Quantification of neutralizing antibodies against RVFV in serum. The titers are given as a $\log _{2}$ reciprocal dilution for the Nubian (A) and LaMancha (B) goats. Data for individual animals is shown with the horizontal bars representing the standard deviations ( $n=3$ on days $2-7 ; n=2$ on days 14-28). Dpi: Days post infection. 


\section{Discussion}

Robust challenge models for RVFV are an important prerequisite for testing novel therapeutics and vaccines and need further development for goats. We have previously established the necessary dose required for infection [35] and have demonstrated that mosquito cell-derived virus leads to more consistent viremia compared to the mammalian cell-derived virus [35]. In this follow-up study, we investigated whether other parameters affect the pathogenicity of RVFV in goats including different breeds of goats, routes of inoculation, and a strain of RVFV from the Kenyan/Sudan outbreak in 2006-2007.

Sequencing and phylogenetic analysis of the virus isolate CFIA-Kenya-UAP determined that the virus clusters with other strains primarily isolated from Sudan, and that its origin is distinct from the Kenyan-128b strain utilized by Faburay and Wilson et al. as well as other commonly used strains such as the Egyptian ZH-501 and ZH-548 strains.

Our previous experiments utilized Alpine-Boer goats infected with the RVFV ZH-501 strain. While infection produced consistent viremia and fever, it did not result in observable clinical disease or significant gross pathology [35]. In contrast, we found that the Kenyan strain used in this study induced mild to moderate clinical symptoms in both the Nubian and LaMancha goats that lasted throughout the acute infection phase (days two-five post infection). Notably, this was not likely due to increased infectious virus production as peak and length of viremia in the LaMancha goats were similar to what we saw in the Alpine-Boer goats. Of the three goat breeds tested, Nubians infected intranasally with the Kenyan strain reached the highest peak viremia titers $\left(10^{5} \mathrm{pfu} / \mathrm{mL}\right)$.

Viral spread to the tissues differed greatly between the goat breeds, with the LaMancha completely lacking virus in any tissue tested at any time point, whereas many organs tested positive for viral RNA in the Nubians at both seven and $28 \mathrm{dpi}$. We first looked at a variety of lymphoid tissues including the spleen that is well known to become infected in sheep and cattle [33,34]. We then investigated other immune tissues including the mesenteric, prescapular, and retropharyngeal lymph nodes. Dendritic cells are thought to be the primary cells to be infected by RVFV, and once activated, they travel to the lymph nodes. We hypothesized that lymph nodes close to the site of infection might be preferentially infected or contain higher amounts of virus. The prescapular lymph node was chosen for its proximity to the subcutaneous injection site behind the shoulder blade, the retropharyngeal lymph node for its proximity to the nasal and oral cavity, and the mesenchymal lymph node as a site distant from either inoculation site. As viremia is present already at one or two dpi, we chose an early time point to look at the lymph nodes. While we did not find detectable virus in the lymph nodes at one dpi and could not distinguish any kinetics, all of the lymph nodes were generally infected in all groups by seven dpi, indicating systemic circulation of the virus.

Previous studies in calves, sheep, and non-human primates have found extensive involvement of the liver in RVFV pathology including lesions, the presence of viral RNA and infectious particles, and changes in blood liver enzymes on days three, four, and five [33,34,40,53]. In contrast, we did not detect high levels of viral RNA in the liver in the Nubian or LaMancha goats by PCR, did not detect viral RNA by in situ hybridization and all liver samples were negative for infectious particles. The only liver sample that was PCR-positive for RVFV was in the Nubian mosquito-primed goats at day 28. With large animals, it is always possible that we simply did not sample an area of the liver that was positive, although we attempted to sample randomly from different areas or would have selected lesions if they had been present. We think it is most likely that the liver was mainly infected during the acute phase of infection, and any liver lesions or impairment may have been resolved in the goats by seven dpi as this is consistent with previous publications [33,34].

Interestingly, we detected substantial levels of viral RNA in different brain tissues in the Nubian goats, although all brain tissues were negative for infectious virus. For example, at one day post infection the trigeminal nerve was positive for viral RNA in the intranasally-infected group. This time point is particularly notable in that it detected neural infection prior to the presence of viremia. This would suggest that neurons could be directly targeted during an intranasal exposure, rather than 
occurring through viremia and a breakdown of the blood brain barrier. Unfortunately though, we were unable to confirm the presence of virus in the trigeminal nerve with in-situ hybridization. We also detected viral RNA in various brain tissues at seven dpi in the subcutaneous and mosquito-primed Nubian groups and in all groups by $28 \mathrm{dpi}$. The most consistently infected brain tissues included the cerebellum, midbrain, and brainstem. RVFV has been detected in the brain in a few other studies as well. For example, in a mouse model of aerosolized RVFV the authors found virus in the neuroepithelium of the olfactory bulb at seven days post infection [38]. In addition, the neurons of 21-day old calves at nine days after subcutaneous infection were positive for RVFV [53]. In vitro cultures of brain tissues from a variety of different ruminants have also been shown to support robust RVFV replication [54]. Notably, our study is the first indication of infected brain tissue in goats, the first to show positivity at such an early time point post infection and the only study to have investigated different regions of the brain.

Whether a difference actually existed between the subcutaneous and mosquito-primed groups in the Nubian goats was difficult to conclude. Certainly, there was no difference in viremia between the two groups. However, the subcutaneous group had a greater number of RVFV RNA positive brain tissues at seven dpi $(n=1)$, while the mosquito-primed group had a great number of RVFV RNA positive brain at $28 \mathrm{dpi}(n=2)$. While this is somewhat striking, the numbers of animals are very small and we cannot discern from this study whether these are due to differences in individual animals or due to the infection method.

In ruminants RVFV transmission appears to be primarily mosquito driven, although results from transmission experiments have been mixed. For example, a few studies in sheep have demonstrated transmission through oral and respiratory routes [41,55-57] as well as through direct contact [41]. We hypothesized that the intranasal infection group might shed virus, and consequently, we measured viral shedding in both nasal and oral swabs. Surprisingly, all three routes of inoculation induced high and similar levels of shedding of viral RNA throughout acute infection in the Nubian goats, while shedding was completely absent in the LaMancha goats. This highlights a potential utility for nasal swabs in diagnostic testing; however, shedding may be breed specifically and requires further investigations for reliability. In contrast, the oral swabs were not as consistent in detecting viral RNA. We think this is likely partly attributable to the fact that we took oral swabs from goats who were alert and active; it was often difficult to get comprehensive coverage of the oral membranes. However, viral RNA was sporadically detected in oral swabs and indicates that a different sampling method would perhaps produce better results. We did not detect any infectious virus in either oral or nasal swabs, suggesting that under our laboratory conditions the risk of transmission from shedding is very low. It is possible that there are high levels of interfering particles present in these samples, which would lead to a much higher viral RNA load compared to infectious virus. We also considered the possibility that inhibitors of viral growth could be present in the swabs, such as antibodies or interferons. Interestingly, we found that nasal swabs that were spiked with RVFV could indeed inhibit virus replication by one to two logs, whereas oral swabs had no effect on RVFV replication. Therefore, we would be able to detect infectious particles in nasal swabs containing $10^{3} \mathrm{pfu} / \mathrm{mL}$ or higher, but lower levels would be inhibited. This suggests that if infectious virus is present in our nasal swabs, it is below $10^{3} \mathrm{pfu} / \mathrm{mL}$, presumably inhibited and not transmissible. Which component in the nasal swab is inhibitory is not yet known, but it would be interesting to identify it. Despite the lack of infectious virus found in our goat swabs, a few studies have demonstrated horizontal transmission from infectious virus isolated from nasal and oral swabs in sheep $[41,55,57]$. Hence, further studies in the field with different breeds, species, or viral strains could be useful.

Both the Nubian and LaMancha goats produced low levels of neutralizing antibodies by three dpi, a sharp increase by $14 \mathrm{dpi}$, and strong peak titers at $21 \mathrm{dpi}$. These kinetics are similar to what we have seen with the Alpine-Boer goats infected with ZH-501 [36], and are similar to what we have seen in sheep challenged with ZH-501 [35]. Peak levels of neutralizing antibodies were generally similar between the LaMancha and Nubian goats, but were somewhat higher than similar groups in the ZH-501 
infected Boer goats [36]. Surprisingly, in contrast to what we have seen previously [35], no difference in neutralizing antibody production was seen between the mammalian and mosquito-derived virus groups in the LaMancha. Based on our previous studies, we hypothesize that the mosquito-derived virus is more efficient at antagonizing interferon responses at the onset of infection, and hence leads to a lower IgG response than the mammalian-derived virus; yet this was not recapitulated in the LaMancha goats. As the LaMancha seemed to be very good at preventing virus infection of the tissues, perhaps this is due to different goat breeds having inherently different susceptibilities and strength of immune responses to RVFV.

\section{Conclusions}

Overall, we have identified a novel goat breed that is useful for RVFV vaccine efficacy testing and have demonstrated that a needle-free intranasal inoculation method produces robust viremia in goats. In addition, we have demonstrated the presence of RVFV RNA in the lymph nodes and the trigeminal nerve at seven dpi after subcutaneous inoculation and many brain tissues remained positive up to 28 days post infection; these tissues could be included as further diagnostic confirmation of RVFV infection in the lab or the field. Importantly, our data also suggests that airborne virus may cause direct invasion of RVFV into the central nervous system rather than through the bloodstream. Finally, a high degree of viral RNA shedding after infection using both subcutaneous and intranasal routes was detected and could be investigated as a non-invasive sampling technique. These findings highlight the impact that a variety of different parameters have on RVFV infection in goats and could be utilized in future vaccine and surveillance studies.

Author Contributions: Conceptualization, H.W., A.L.K.; Methodology, E.M., R.L.; Formal Analysis, A.L.K., C.E.-H., B.C., O.L.; Investigation, A.L.K., V.S., O.L.; Resources, R.L. Data Curation, A.L.K.; Writing-Original Draft Preparation, A.L.K.; Writing一Review \& Editing, A.L.K., H.W.; Visualization, A.L.K.; Supervision, A.L.K., H.W.; Project Administration, A.L.K.; Funding Acquisition, H.W.

Funding: This research was funded by the Canadian Safety and Security Program (\#2016-TI-2221) through the Biosafety Level 4 Zoonotic Disease Laboratory Network (BSL4ZNET).

Acknowledgments: We graciously acknowledge the help of our dedicated animal care staff at NCFAD and our lab manager Peter Marszal for his training, expertise and support throughout this project.

Conflicts of Interest: The authors declare no conflicts of interest.

\section{References}

1. Liu, J.; Sun, Y.; Shi, W.; Tan, S.; Pan, Y.; Cui, S.; Zhang, Q.; Dou, X.; Lv, Y.; Li, X.; et al. The first imported case of Rift Valley fever in China reveals a genetic reassortment of different viral lineages. Emerg Microbes Infect. 2017, 6, e4. [CrossRef]

2. Gür, S.; Kale, M.; Erol, N.; Yapici, O.; Mamak, N.; Yavru, S. The first serological evidence for Rift Valley fever infection in the camel, goitered gazelle and Anatolian water buffaloes in Turkey. Trop. Anim. Health Prod. 2017, 49, 1531-1535. [CrossRef]

3. Bett, B.; Kiunga, P.; Gachohi, J.; Sindato, C.; Mbotha, D.; Robinson, T.; Lindahl, J.; Grace, D. Effects of climate change on the occurrence and distribution of livestock diseases. Prev. Vet. Med. 2017, 137, 119-129. [CrossRef]

4. Balkhy, H.H.; Memish, Z.A. Rift Valley Fever: an uninvited zoonosis in the Arabian peninsula. Int J Antimicrob Agents. 2003, 21, 153-157. [CrossRef]

5. Bird, B.H.; Bawiec, D.A.; Ksiazek, T.G.; Shoemaker, T.R.; Nichol, S.T. Highly sensitive and broadly reactive quantitative reverse transcription-PCR assay for high-throughput detection of Rift Valley fever virus. J. Clin. Microbiol. 2007, 45, 3506-3513. [CrossRef]

6. Chevalier, V. Relevance of Rift Valley fever to public health in the European Union. Clin Microbiol Infect. 2013, 19, 705-708. [CrossRef]

7. Chevalier, V.; Pepin, M.; Plee, L.; Lancelot, R. Rift Valley fever-a threat for Europe? Euro Surveill. 2010, 10, 19506. [CrossRef] 
8. Davies, F.G.; Linthicum, K.J.; James, A.D. Rainfall and epizootic Rift Valley fever. Bull. World Health Organ. 1985, 63, 941-943.

9. Hassan, O.A.; Ahlm, C.; Sang, R.; Evander, M. The 2007 Rift valley fever outbreak in Sudan. PLoS Negl. Trop. Dis. 2011. [CrossRef]

10. Leedale, J.; Jones, A.E.; Caminade, C.; Morse, A.P. A dynamic, climate-driven model of rift valley fever. Geospat. Health 2016, 11. [CrossRef]

11. Redding, D.W.; Tiedt, S.; Lo Iacono, G.; Bett, B.; Jones, K.E. Spatial, seasonal and climatic predictive models of Rift Valley fever disease across Africa. Philos. Trans. R. Soc. B Biol. Sci. 2017, 372, 20160165. [CrossRef]

12. Napp, S.; Chevalier, V.; Busquets, N.; Calistri, P.; Casal, J.; Attia, M.; Elbassal, R.; Hosni, H.; Farrag, H.; Hassan, N.; et al. Understanding the legal trade of cattle and camels and the derived risk of Rift Valley Fever introduction into and transmission within Egypt. PLoS Negl. Trop. Dis. 2018, 12. [CrossRef]

13. Brustolin, M.; Talavera, S.; NuÑez, A.; SantamarÍa, C.; Rivas, R.; Pujol, N.; Valle, M.; Verdún, M.; Brun, A.; Pagès, N.; et al. Rift Valley fever virus and European mosquitoes: Vector competence of Culex pipiens and Stegomyia albopicta (= Aedes albopictus). Med. Vet. Entomol. 2017, 31, 365-372. [CrossRef]

14. Ndiaye, E.H.; Fall, G.; Gaye, A.; Bob, N.S.; Talla, C.; Diagne, C.T.; Diallo, D.; BA, Y.; Dia, I.; Kohl, A.; et al. Vector competence of Aedes vexans (Meigen), Culex poicilipes (Theobald) and Cx. quinquefasciatus Say from Senegal for West and East African lineages of Rift Valley fever virus. Parasites Vectors 2016, 9. [CrossRef]

15. Turell, M.J.; Britch, S.C.; Aldridge, R.L.; Xue, R.; De Smith, M.L.; Cohnstaedt, L.W.; Linthicum, K.J. Potential for Psorophora columbiae and Psorophora ciliata Mosquitoes (Diptera: Culicidae) to Transmit Rift Valley Fever Virus. J. Med. Entomol. 2015, 52, 1111-1116. [CrossRef]

16. Coetzer, J.A. The pathology of Rift Valley fever. I. Lesions occurring in natural cases in new-born lambs. Onderstepoort J. Vet. Res. 1977, 4, 205-211.

17. Coetzer, J.A. The pathology of Rift Valley fever. II. Lesions occurring in field cases in adult cattle, calves and aborted foetuses. Onderstepoort J. Vet. Res. 1982, 1, 11-17.

18. Archer, B.N.; Thomas, J.; Weyer, J.; Cengimbo, A.; Landoh, D.E.; Jacobs, C.; Ntuli, S.; Modise, M.; Mathonsi, M.; Blumberg, L.; et al. Epidemiologic investigations into outbreaks of Rift Valley fever in humans, South Africa, 2008-2011. Emerg. Infect. Dis. 2013, 19, 1918-1925. [CrossRef]

19. Métras, R.; Porphyre, T.; Pfeiffer, D.U.; Kemp, A.; Thompson, P.N.; Collins, L.M.; White, R.G. Exploratory Space-Time Analyses of Rift Valley Fever in South Africa in 2008-2011. PLoS Negl. Trop. Dis. 2012, 6. [CrossRef]

20. Monaco, F.; Pinoni, C.; Cosseddu, G.M.; Khaiseb, S.; Calistri, P.; Molini, U.; Bishi, A.; Conte, A.; Scacchia, M.; Lelli, R. Rift Valley fever in Namibia, 2010. Emerg. Infect. Dis. 2013, 19, 2025-2027. [CrossRef]

21. Nicholas, D.E.; Jacobsen, K.H.; Waters, N.M. Risk factors associated with human Rift Valley fever infection: Systematic review and meta-analysis. Trop. Med. Int. Health 2014, 19. [CrossRef]

22. Ikegami, T.; Makino, S. The pathogenesis of rift valley fever. Viruses 2011, 3, 493-519. [CrossRef]

23. Nguku, P.M.; Sharif, S.K.; Mutonga, D.; Amwayi, S.; Omolo, J.; Mohammed, O.; Farnon, E.C.; Gould, L.H.; Lederman, E.; Rao, C.; et al. An investigation of a major outbreak of rift valley fever in Kenya: 2006-2007. Am. J. Trop. Med. Hyg. 2010, 83 (Suppl. 2), 5-13. [CrossRef]

24. Sow, A.; Faye, O.; Ba, Y.; Ba, H.; Diallo, D.; Faye, O.; Loucoubar, C.; Boushab, M.; Barry, Y.; Diallo, M.; et al. Rift valley fever outbreak, Southern Mauritania, 2012. Emerg. Infect. Dis. 2014, 20, 296-299. [CrossRef]

25. Dungu, B.; Louw, I.; Lubisi, A.; Hunter, P.; von Teichman, B.F.; Bouloy, M. Evaluation of the efficacy and safety of the Rift Valley Fever Clone 13 vaccine in sheep. Vaccine 2010, 28, 4581-4587. [CrossRef]

26. Indran, S.V.; Ikegami, T. Novel approaches to develop Rift Valley fever vaccines. Front. Cell. Infect. Microbiol. 2012, 2. [CrossRef]

27. Kortekaas, J.; Antonis, A.F.G.; Kant, J.; Vloet, R.P.M.; Vogel, A.; Oreshkova, N.; de Boer, S.M.; Bosch, B.J.; Moormann, R.J.M. Efficacy of three candidate Rift Valley fever vaccines in sheep. Vaccine 2012, 30, 3423-3429. [CrossRef]

28. Mansfield, K.L.; Banyard, A.C.; McElhinney, L.; Johnson, N.; Horton, D.L.; Hernández-Triana, L.M.; Fooks, A.R. Rift Valley fever virus: A review of diagnosis and vaccination, and implications for emergence in Europe. Vaccine 2015. [CrossRef]

29. Morrill, J.C.; Laughlin, R.C.; Lokugamage, N.; Wu, J.; Pugh, R.; Kanani, P.; Adams, L.G.; Makino, S.; Peters, C.J. Immunogenicity of a recombinant Rift Valley fever MP-12-NSm deletion vaccine candidate in calves. Vaccine 2013, 31, 4988-4994. [CrossRef] 
30. Pittman, P.R.; McClain, D.; Quinn, X.; Coonan, K.M.; Mangiafico, J.; Makuch, R.S.; Morrill, J.; Peters, C.J. Safety and immunogenicity of a mutagenized, live attenuated Rift Valley fever vaccine, MP-12, in a Phase 1 dose escalation and route comparison study in humans. Vaccine 2016, 34, 424-429. [CrossRef]

31. Soi, R.K.; Rurangirwa, F.R.; McGuire, T.C.; Rwambo, P.M.; DeMartini, J.C.; Crawford, T.B. Protection of sheep against Rift Valley fever virus and sheep poxvirus with a recombinant capripoxvirus vaccine. Clin. Vaccine Immunol. 2010, 17, 1842-1849. [CrossRef]

32. Warimwe, G.M.; Lorenzo, G.; Lopez-Gil, E.; Reyes-Sandoval, A.; Cottingham, M.G.; Spencer, A.J.; Collins, K.A.; Dicks, M.D.; Amar Lall, A.M.; Furze, J.; et al. Immunogenicity and efficacy of a chimpanzee adenovirus-vectored Rift Valley Fever vaccine in mice. Virol. J. 2013, 10. [CrossRef]

33. Wilson, W.C.; Davis, A.S.; Gaudreault, N.N.; Faburay, B.; Trujillo, J.D.; Shivanna, V.; Sunwoo, S.Y.; Balogh, A.; Endalew, A.; Ma, W.; et al. Experimental infection of calves by two genetically-distinct strains of rift valley fever virus. Viruses 2016, 8, 145. [CrossRef]

34. Faburay, B.; Gaudreault, N.N.; Liu, Q.; Davis, A.S.; Shivanna, V.; Sunwoo, S.Y.; Lang, Y.; Morozov, I.; Ruder, M.; Drolet, B.; et al. Development of a sheep challenge model for Rift Valley fever. Virology 2016, 489, 128-140. [CrossRef]

35. Weingartl, H.M.; Miller, M.; Nfon, C.; Wilson, W.C. Development of a rift valley fever virus viremia challenge model in sheep and goats. Vaccine 2014, 32, 2337-2344. [CrossRef]

36. Nfon, C.K.; Marszal, P.; Zhang, S.; Weingartl, H.M. Innate immune response to rift valley fever virus in goats. PLoS Negl. Trop. Dis. 2012, 6. [CrossRef]

37. Le Coupanec, A.; Babin, D.; Fiette, L.; Jouvion, G.; Ave, P.; Misse, D.; Bouloy, M.; Choumet, V. Aedes Mosquito Saliva Modulates Rift Valley Fever Virus Pathogenicity. PLoS Negl. Trop. Dis. 2013, 7. [CrossRef]

38. Reed, C.; Lin, K.; Wilhelmsen, C.; Friedrich, B.; Nalca, A.; Keeney, A.; Donnelly, G.; Shamblin, J.; Hensley, L.E.; Olinger, G.; et al. Aerosol Exposure to Rift Valley Fever Virus Causes Earlier and More Severe Neuropathology in the Murine Model, which Has Important Implications for Therapeutic Development. PLoS Negl. Trop. Dis. 2013, 7. [CrossRef]

39. Hartman, A.L.; Powell, D.S.; Bethel, L.M.; Caroline, A.L.; Schmid, R.J.; Oury, T.; Reed, D.S. Aerosolized Rift Valley Fever Virus Causes Fatal Encephalitis in African Green Monkeys and Common Marmosets. J. Virol. 2014, 88, 2235-2245. [CrossRef]

40. Smith, D.R.; Bird, B.H.; Lewis, B.; Johnston, S.C.; McCarthy, S.; Keeney, A.; Botto, M.; Donnelly, G.; Shamblin, J.; Albariño, C.G.; et al. Development of a novel nonhuman primate model for Rift Valley fever. J. Virol. 2012, 86, 2109-2120. [CrossRef]

41. Yedloutschnig, R.J.; Dardiri, A.H.W.J. Rift Valley Fever Infection in sheep by contact exposure. Contr. Epidem. Biostat. 1981, 3, 53-59.

42. Moutailler, S.; Roche, B.; Thiberge, J.M.; Caro, V.; Rougeon, F.; Failloux, A.B. Host alternation is necessary to maintain the genome stability of Rift Valley fever virus. PLoS Negl. Trop. Dis. 2011, 5. [CrossRef]

43. Weingartl, H.M.; Zhang, S.; Marszal, P.; McGreevy, A.; Burton, L.; Wilson, W. Rift Valley Fever Virus Incorporates the $78 \mathrm{kDa}$ Glycoprotein into Virions Matured in Mosquito C6/36 Cells. PLoS ONE 2014, 9, e87385. [CrossRef]

44. Jones, D.T.; Taylor, W.R.; Thornton, J.M. The rapid generation of mutation data matrices from protein sequences. Comput. Appl. Biosci. 1992, 8, 275-282. [CrossRef]

45. Felsenstein, J. Confidence limits on phylogenies: An approach using the bootstrap. Evolution 1985, 39, 783-791. [CrossRef]

46. Kumar, S.; Stecher, G.; Tamura, K. MEGA7: Molecular Evolutionary Genetics Analysis version 7.0 for bigger datasets. Mol. Biol. Evol. 2016, 33, 1870-1874. [CrossRef]

47. Espach, A.; Romito, M.; Nel, L.H.; Viljoen, G.J. Development of a diagnostic one-tube RT-PCR for the detection of Rift Valley fever virus. Onderstepoort J. Vet. Res. 2002, 69, 247-252.

48. Schaeffer, E.; Flacher, V.; Papageorgiou, V.; Decossas, M.; Fauny, J.; Kramer, M.; Mueller, C. Dermal CD14+ dendritic cell and macrophage infection by dengue virus is stimulated by interleukin-4. J. Investig. Dermatol. 2015, 135, 1743-1751. [CrossRef]

49. Klimstra, W.B.; Nangle, E.M.; Smith, M.S.; Yurochko, A.D.; Ryman, K.D. DC-SIGN and L-SIGN can act as attachment receptors for alphaviruses and distinguish between mosquito cell- and mammalian cell-derived viruses. J. Virol. 2003, 77, 12022-12032. [CrossRef] 
50. Agarwal, A.; Joshi, G.; Nagar, D.P.; Sharma, A.K.; Sukumaran, D.; Pant, S.C.; Pant, S.C.; Parida, M.M.; Dash, P.K. Mosquito saliva induced cutaneous events augment Chikungunya virus replication and disease progression. Infect. Genet. Evol. 2016, 40, 126-135. [CrossRef]

51. Styer, L.M.; Lim, P.-Y.; Louie, K.L.; Albright, R.G.; Kramer, L.D.; Bernard, K.A. Mosquito Saliva Causes Enhancement of West Nile Virus Infection in Mice. J. Virol. 2011, 85, 1517-1527. [CrossRef]

52. Wichit, S.; Ferraris, P.; Choumet, V.; Missé, D. The effects of mosquito saliva on dengue virus infectivity in humans. Curr. Opin. Virol. 2016. [CrossRef]

53. Rippy, M.K.; Topper, M.J.; Mebus, C.A.; Morrill, J.C. Rift Valley Fever Virus-induced Encephalomyelitis and Hepatitis in Calves. Vet. Pathol. 1992, 29, 495-502. [CrossRef]

54. Gaudreault, N.N.; Indran, S.V.; Bryant, P.K.; Richt, J.A.; Wilson, W.C. Comparison of Rift Valley fever virus replication in NOrth American livestock and wildlife cell lines. Front. Microbiol. 2015, 6, 664. [CrossRef]

55. Busquets, N.; Xavier, F.; Martín-Folgar, R.; Lorenzo, G.; Galindo-Cardiel, I.; del Val, B.P.; Rivas, R.; Iglesias, J.; Rodríguez, F.; Solanes, D.; et al. Experimental infection of young adult European breed sheep with Rift Valley fever virus field isolates. Vector Borne Zoonotic Dis. 2010, 10, 689-696. [CrossRef]

56. Easterday, B.C.; Mcgavran, M.H.; Rooney, J.R.; Murphy, L.C. The pathogenesis of Rift Valley fever in lambs. Am. J. Vet. Res. 1962, 23, 470-479.

57. Harrington, D.G.; Lupton, H.W.; Crabbs, C.L.; Peters, C.J.; Reynolds, J.A.; Slone, T.W. Evaluation of a formalin-inactivated Rift Valley fever vaccine in sheep. Am. J. Vet. Res. 1980, 41, 1559-1564.

(C) 2018 by the authors. Licensee MDPI, Basel, Switzerland. This article is an open access article distributed under the terms and conditions of the Creative Commons Attribution (CC BY) license (http://creativecommons.org/licenses/by/4.0/). 